\title{
鼻粘膜のフィブロネクチンと好酸球の検討
}

\author{
高村 博光・高崎 賢治・弦本 日芳
}

\section{Immunohistochemical Study of the Human Nasal Mucosa for Fibronectin and Eosinophils}

\author{
Hiromitsu Takamura, Kenji Takasaki and Hiyoshi Tsurumoto \\ (Nagasaki University School of Medicine)
}

The distribution of fibronectin, an extracellular matrix component, was examined in patients with nasal allergy and in non-allergic patients. The distribution and the number of EG2 positive cells in the nasal mucosa was investigated with respect to the clinical effects of anti-allergic agents.

We investigated 11 patients with nasal allergy ( 5 males and 6 females, age 19 to 57 years) and 8 non allergic patients ( 6 males and 2 females, age 16 to 72 years). Biopsy specimens were obtained from the inferior turbinate under general or local anesthesia, and then frozen at $-70^{\circ} \mathrm{C}$. The samples were then sectioned to a thickness of $4 \mu \mathrm{m}$ using a cryostat. The presence of fibronectin, EG2 positive cells and macrophages was then identified using each monoclonal antibodies and streptavidin-biotin peroxidase complex staining method (DAKO).

In this study, we found that fibronectin was distributed mainly around the basement membrane and vessel walls, and its distribution was similar between patients with nasal allergy and non-allergic patients. The clinical effects of anti-allergic agents correlated well with the number of EG2 positive cells in the superficial layer, but not with the distribution of fibronectin in the nasal mucosa.

Key words : fibronectin, eosinophil, nasal allergy

\section{はじめに}

アレルギー性炎症に拈いて, 種々の細胞が局所で重要 な役割を演じていることは数多く論じられており，最近 では血管内皮細胞や細胞外マトリックスと白血球との接 着に扣いてインテグリンファミリー, Igスーパーファ ミリー, セレクチンファミリー等の接着分子の関与が明 らかにされ, これらを介した組織への接着, 浸潤, さら には組織内での作用等が注目を集めている1). 今回, わ れわれは鼻アレルギー患者扣よび非アレルギー患者の下 鼻甲介粘膜を用い, リンパ球や好酸球等の細胞に発現す るVLA-4 やVLA-5などインテグリンファミリーに属 する接着分子に対するリガンドとされる細胞外マトリッ クスであるフィブロネクチンに注目し，その局在を中心
に免疫組織学的(LSAB 法)に検討した。また，抗アレ ルギー斉である塩酸アゼラスチン投与前後におけるフィ ブロネクチン扣よび活性化好酸球である EG2 陽性細胞 数についてその影響をみるとともに濾胞を形成した部分 については抗フィブロネクチン抗体に加え, マクロフ ァージを認識する抗 CD11c 抗体を用い検討した.

\section{対象と方法}

\section{1 ) 対 象}

平成 6 年㐨よび平成 7 年に長崎大学医学部耳鼻咽喉科, 長崎原爆病院耳鼻咽喉科, 長崎三菱病院耳鼻咽喉科を受 診し，通年性鼻アレルギーと診断された男性 5 名，女性 6 名, 年齡は19歳から57歳まで(このらち薬阂投与の検 
討は男性 2 名,女性 3 名, 年齢19歳から27歳まで(表 1 )), 非アレルギーと診断された入院患者(全て慢性副鼻腔炎) で男性 6 名, 女性 2 名, 年齢は16歳から72歳までであっ た.アレルギーの診断として鼻症状があり，鼻汁中好酸 球陽性かつ抗原が同定できたもの（全例 HD 陽性であっ たをアレルギーと診断し，非アレルギーの診断は皮内 反応あるいは RAST，鼻粘膜誘発反応，鼻汁中好酸球 等のアレルギー検査がすべて陰性であることとした。な お，鼻アレルギー患者(薬剤投与前含む)については鼻粘 膜切除は初診時あるいは少なくとも2 週間以上鼻アレル ギーに対して投薬等加療を行っていない時点で行ってい る. 薬剤投与例では薬物投与前および塩酸アゼラスチン $1 \mathrm{mg}$ 錠 1 日 2 回投与 4 週間後にそれぞれ下鼻甲介粘膜 切除を施行した。

2）方 法

鼻アレルギー患者については下鼻甲介粘膜前端部を 4 \%キシロカインにより表面麻酔を行った後切除, 非アレ ルギー患者については局所麻酔, 全身麻酔下の鼻, 副鼻 腔手術の際に同部を切除した。尚，粘膜切除については 事前に患者に十分説明を行い承諾を得た後施行している。 アセトンドライアイスにて $-70^{\circ} \mathrm{C}$ に凍結保存, クリオ スタットにて $4 \mu \mathrm{m}$ の凍結切片を作成し, 室温乾燥, 4 ${ }^{\circ} \mathrm{C}$ アトンで10分間固定，3\%過酸化水素にて内因性 ペルオキシダーゼ除去, 正常ヤギ血清にて非特異的反応 を阻止した後，一次抗体としてモノクローナル抗体であ る抗フィブロネクチン抗体(アフィニティーリサーチプ ロダクト社, FG-6010) $\mathrm{EG}_{2}$ 抗体 (pharmacia) および抗 $\mathrm{CD} 11 \mathrm{c}$ 抗体(セイガクコーポレーション)(それぞれ 37 ${ }^{\circ} \mathrm{C} 20$ 分間反応), 二次抗体にビオチン標識抗マウス免疫 グロブリン・ヤギ抗体 $\left(37^{\circ} \mathrm{C} 10\right.$ 分 $)$, 酵素試薬にペルオ

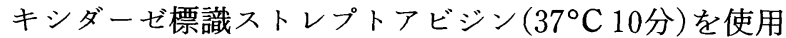
し, 発色基質に $3 \%$ AEC を使って発色させ, マイヤー のヘマトキシリンにより核染色を行いAQUATEX (メ ルク社製)にて封入，顕微鏡下に観察した。また，陰性 コントロールとして一次抗体のかわりにウサギ正常血清 を用い染色されないことを確認した。洗い出しには TBS (pH : 7.6) を使用した。また，EG2 陽性細胞数の カウントは粘膜固有層浅層を上皮下の固有層, 粘膜固有 層深層をさらに深い部位で細胞浸潤が比較的均一な部位 とし，400倍で 3 カ所カウントし，その平均を採用した. なお，マクロファージについては鼻アレルギー下甲介粘 膜に扣いて抗 CD11c 抗体と抗 CD68 抗体を用い検討を 行ったが今回, 濾胞の認められた切片については抗 CD 11c 抗体を一次抗体として使用した。

\section{結 果}

1）鼻アレルギー患者下甲介粘膜に括けるフィブロネ クチンの分布について

フィブロネクチンは下甲介粘膜において上皮層では肥 厚した基底膜に強く陽性を示したが，上皮細胞ではすべ ての症例で汪とんど染色されなかった（図1）。また，円 形細胞周辺に強く陽性を示す部位もあった．粘膜固有層 では, 血管内皮扣よびその周囲に特に強く陽性を示し（図 2 ), 間質でも染色されたが固有層浅層と深層で差は認 められず,腺細胞では皃とんど染色されなかった（図 3 ). また濾胞を形成した部分にもフィブロネクチンが比較的 大型の細胞に陽性を示し，樹枝状の形態をとり（図 4 ) 同 一の濾胞に打けるマクロファージと分布，数が非常に類 似していた(図 5 ).

2 ) 非アレルギー患者の下甲介粘膜に括けるフィブロ

表 1 抗アレルギー剤投与の影響

\begin{tabular}{|c|c|c|c|c|c|c|c|}
\hline \multirow{3}{*}{ 症例 } & \multirow{3}{*}{ 年齢/性 } & \multicolumn{4}{|c|}{$\mathrm{EG}_{2}$ 陽性細胞数(個) $(\times 400)$} & \multirow{3}{*}{ 臨床症状 } & \multirow{3}{*}{ 局所所見 } \\
\hline & & \multicolumn{2}{|c|}{ 薬剂投与前 } & \multicolumn{2}{|c|}{ 薬剤投与後 } & & \\
\hline & & 浅層 & 深層 & 线層 & 深層 & & \\
\hline 1 & 21 女 & 16.7 & 2.7 & 10.7 & 5.7 & 改善 & 軽度改善 \\
\hline 2 & 19 女 & 40.7 & 1.3 & 20.0 & 5.7 & 改善 & 軽度改善 \\
\hline 3 & 25 男 & 40.7 & 1.7 & 39.3 & 2.3 & 不変 & 不変 \\
\hline 4 & 27 男 & 52.7 & 1.3 & 48.7 & 14.0 & 増悪 & やや増悪 \\
\hline 5 & 21 女 & 49.3 & 47.3 & 36.7 & 8.3 & 軽度改善 & 軽度改善 \\
\hline
\end{tabular}




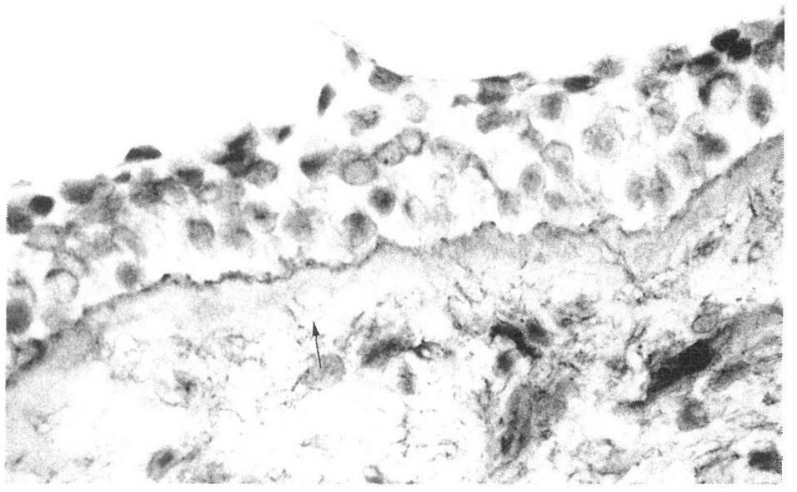

図 1 基底膜に批りつィブロネクチンの分布 $(\times 400)$ (LSAB法) フィブロネクチンが基底膜に陽性を示した(矩印)。

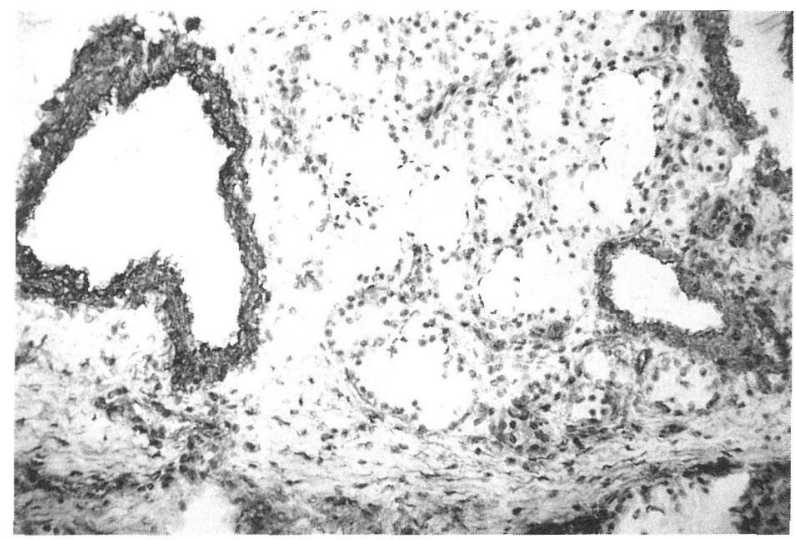

図 2 粘膜固有層に括けるフィブロネクチンの分布 $(\times 100)$ (LSAB 法)

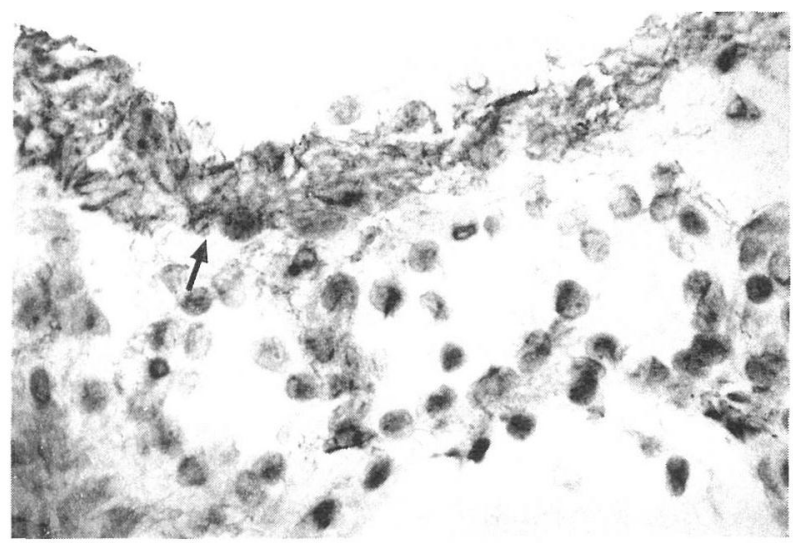

図 3 血管周囲, 腺細胞に拉けるフィブロネクチンの分布 $(\times$ 400) (LSAB 法)

血管执よびその周团ではフィブロネクチンは強く陽性を 示すが腺細胞(矢印)では染色されない。

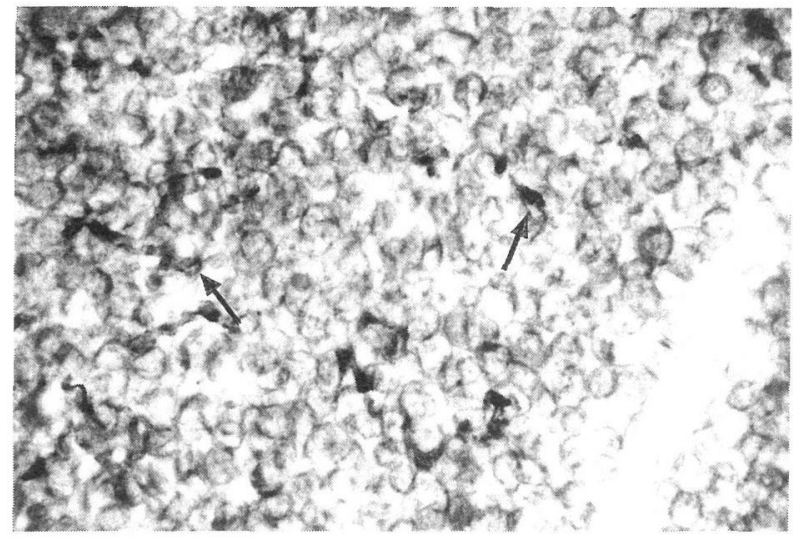

図 4 濾胞部位に护けるフィブロネクチンの分布 $(\times 400)$ (LSAB法) 濾胞内にフィブロネクチン(大印)が陽性を示した。

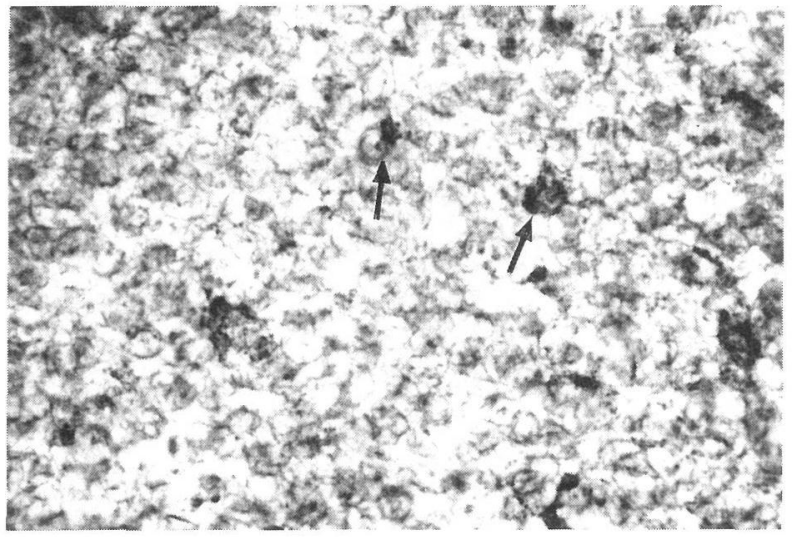

図 5 濾胞部位に利けるマクロファージの分布 $(\times 400)(\mathrm{LSAB}$ 法)

濾胞内にマクロファージ(矢印)が認められ，フィブロネ クチンと分布数が類似していた。

ネクチンの分布について

非アレルギー患者に拈いても鼻アレルギー患者と同様 に基底膜，血管执よびその周囲，腺周囲に陽性を示した が(図6)鼻アレルギーの有無に打いても亦た非アレル ギー症例の各症例間にても差は認められなかった。さら に上皮細胞直下に拈いて上皮剥離とフィブロネクチンの 発現にも一定の傾向はなかった。

3) 抗アレルギー剂投与の影響について

フィブロネクチンの分布については投与前後に和いて 基底膜，血管およびその周囲，腺周囲等で明らかな発現 の変化は認められなかった（図７），EG2 陽性細胞につ いては上皮層，粘膜固有層浅層を中心に陽性細胞を認め 


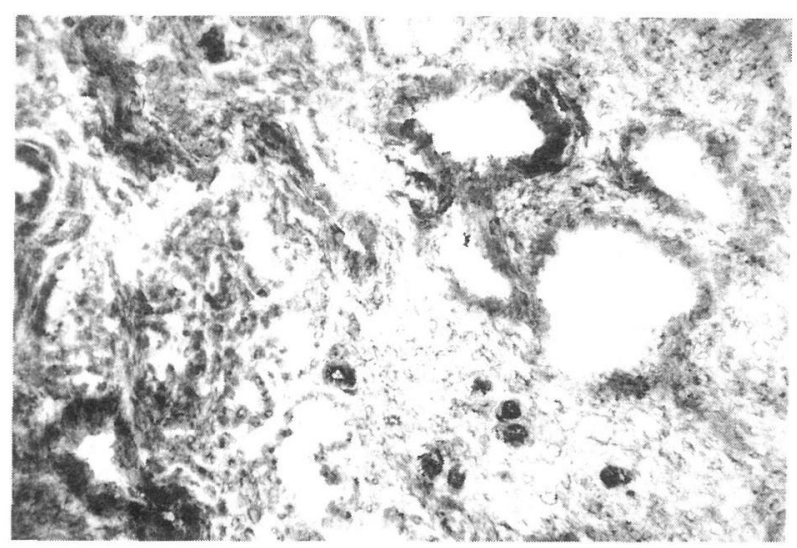

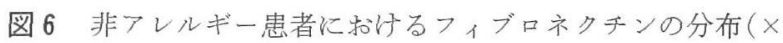
100) (LSAB 法)

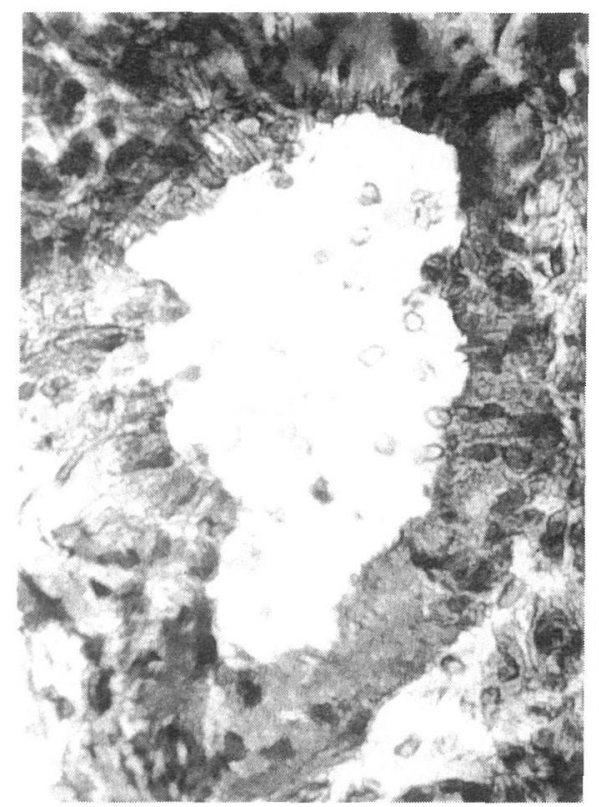

図 7 抗アレルギー剂投与前後におけるフィブロネクチン(血管周团)の分布 (左 : 投与 前, 右: 投与後) (×400) (LSAB 法)

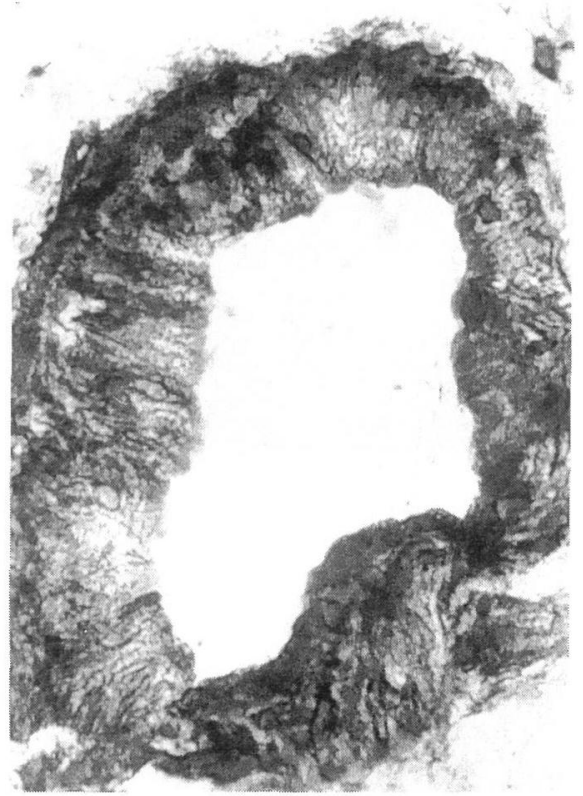

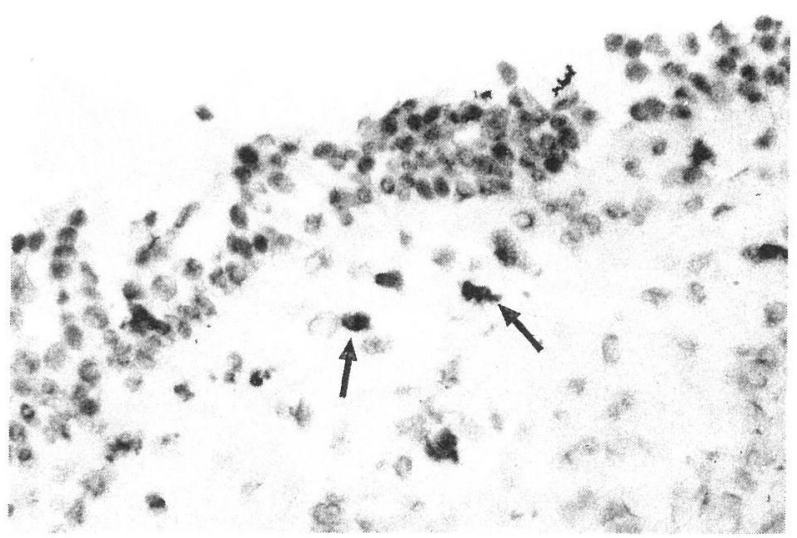

図 8 鼻アレルギー患者下甲介粘膜中の EG2 陽性細胞 $(\times 200)$ (LSAB 法)

下甲介粘膜浅層を中心に EG2 陽性細胞が認められた。
(図 8 ), 浅層に括いては 5 例中 3 例で減少傾向，2 例は 活湾不変, 深層では減少 1 例, 増加 3 例, 不変 1 例で深 層については一定の傾向は認められなかった。臨床症状， 局所所見の変化と比較すると浅層に沶いて EG2 陽性細 胞数減少老認めた症例でいずれも改善傾向が認められた (表 1).
考察

フィブロネクチンはVLA-3, 4, 5 や $\beta 3$ インテグリン に属する接着分子に対するリガンドである2).フィブロ ネクチンは主に血液中に存在するが細胞外マトリックス にも存在する糖蛋白で, 主要な生理活性を示すと1) 細 胞接着, 伸展の促進, 2 ) 細胞移動の促進, 3 ) 細胞分化 の調節，4) 組織修復などがあり3)，またフィブロネク 
チンはオプソニンとしてマクロファージの貪食作用を促 進し，組織崩壊物の除去にも関与している4).アレルギー 疾患に括いては，最近では血夜中から組織中に侵入した 好酸球が VLA-4 を介してフィブロネクチンと接着し機 能を発揮し, 結果的に好酸球の生存延長にも関与してい る5゙などの報告やフィブロネクチンとの接着により LTC4 の産生促進が起こるとの報告もあり6) 注目されて いる．過去慢性副鼻腔炎の副鼻腔粘膜に打ける検討では 血管周囲でのフィブロネクチン発現が認められている7) が未だその報告は多いとはいえず今後他の鼻疾患に执い ても検討が必要と思われる。またマスト細胞においては FcERI を介したマスト細胞の活性化が VLA-4， VLA-5 といったインテグリン分子を介したフィブロネクチンへ の接着により増強することが明らかになっており，一般 に粘膜や皮下組織など細胞外マトリックスに富む環境に 存在するマスト細胞が低濃度で抗原に反応できることに これらインテグリンのングナルの関与が重要であると考 えられている8).

さらにフィブロネクチンは線維芽細胞や血管内皮細胞, 平滑筋細胞, マクロファージから分泌されることが知ら れて㧊り9), 正常血管壁内膜での存在も観察されている. 今回われわれが下甲介粘膜を用いた結果，フィブロネク チンが血管周囲や基底膜に強く発現していたことはこれ らの事実と関連していると考えられ，さらにVLA-4 等 を介した好酸球等の炎症細胞の集積，浸潤への関与も今 後興味がもたれると思われた。 また，滤胞内でフィブロ ネクチンが散在性に陽性を示した部位でフィブロネクチ ンレセプターをもつ CD11c 陽性細胞であるマクロフ ァージと相関が認められたことは分泌されたフィブロネ クチン自体かレセプター部位に一致して存在したフィブ ロネクチンが観察されたのではないかと考えている.

角膜に扮いては上皮欠損に批いて欠損部の実質表面に 強くフィブロネクチンが観察されている10)が, 今回の 切除粘莫に扣ける上皮剥離部位でフィブロネクチンの分 布に一定の傾向がなかったことは粘膜切除あるいは切片 作成の際に上皮が剥離した可能性もあるため今後上皮, 基底膜の部位にも注目しながら検討していきたい．

抗アレルギー阂の投与の影響については症例が 5 例と 少なかったものの今回の結果のみから考察すると抗アレ ルギー㶡投与により粘膜固有層深層の活性化好酸球浸潤 にあまり変化はみられず浅層において $\mathrm{EG}_{2}$ 陽性細胞数 が減少していたことから組織内での好酸球活性化抑制に
おける抗アレルギー風の関与が考えられた。しかしなが ら組織に浸潤した好酸球はかなりの割合ですでに活性化 している可能性もあり, 活性化好酸球の組織内浸潤, 粘 膜固有層浅層への組織内移動に対する抗アレルギー剤の 関与も考兄られると思ら。

また抗アレルギー剤投与に怙いてフィブロネクチンの 分布には明らかな変化が認められなかったことからフィ ブロネクチン発現の強さと好酸球の組織内に打ける局在 との関与を明らかにするのは困難であった.

今後症例を增やすと共にフィブロネクチンレセプター 等の局在, 鼻茸その他の鼻疾患に打いても同様に検討し ていきたいと思う。

\section{まとめ}

1 、鼻アレルギー患者および非アレルギー患者の下鼻 甲介粘膜を用い，細胞外マトリックスであるフィブロネ クチンの分布について兔度組織学的に検討した.ささらに 抗アレルギー剤の投与によるフィブロネクチンの分布, 活性化好酸球への影響について子考察した。

2. 鼻アレルギー患者に打いてはフィブロネクチンは 基底膜, 血管内皮拈よびその周囲に強く陽性を示した。 非アレルギー患者においても同様の傾向を示し，アレル ギーの有無に扣いて明らかな差異は認められなかった。

3. 抗アレルギー剂投与前後に打いてフィブロネクチ ンの発現に差は認められなかったが活性化好酸球数は投 与後で粘膜固有層浅層に打いて減少傾向が認められた。

本論文の要旨は第34回日本鼻科学会(平成 7 年10月), 第45回 日本アレルギー学会(平成 7 年10月)に扎いてロ演した.

\section{参考文献}

1 ) 八木田秀雄：アレルギーと接着分子. アレルギーの領域(宮 本昭正, 石川 哮, 飯倉洋治編). 668 674頁, 医薬ジャ一 ナル社, 大阪, 1994.

2 ) 寺木祐一, 塩原哲夫 : 皮膚と接着分子. アレルギーの領域 (宮本昭正, 石川 哮, 飯倉洋治編). $700 \sim 706$ 頁, 医薬シ ヤーナル社, 大阪, 1994 .

3 ）林 正男：細胞外マトリックス蛋白質. 接着分子(宮坂昌 之編). 1 11頁, 中外医薬社, 東京, 1993.

4 ) Bevilacqua MP, Amrani D, Mosesson MW, et al : Receptors for cold-insoluble globulin (plasma fibronectin) on human monocytes. J Exp Med 153 : 42 60, 1981.

5 ) Anwar ARF, Moqbel R, Walsh GM, et al : Adhesion to 
fibronectin prolongs eosinophil survival. J Exp Med 177 : 839 843, 1993.

6 ) Neeley SP, Hanman KJ, Dowling TL, et al : Augmentation of stimulated eosinophil degranulation by VLA-4 (CD49 d)-mediated adhesion to fibronectin. Am J Respir Cell Mol Biol 11 : 206 213, 1994.

7 ) Ishida $M$, Matsunaga $T$ and Uda $H$ : An immunohistological study of nasaland paranasal mucosa of patients with relapsing chronic sinusitis. Rhinology $22: 115 \sim 118$, 1984 .

8 ）安田勝彦，八木田秀雄：マスト細胞の活性化と接着分子.
臨床免疫 $26: 124 \sim 132,1994$.

9 ）関口清俊, 市原啓子：フィブロネクチンマトリックスの形 成機構. 実験医学 11：119 126, 1993.

10）西田輝夫：上皮創傷治癒における細胞外マトリックスの役 割. 実験医学 $11 ： 151 \sim 155,1993$.

原稿受付: 平成 7 年12月 4 日 原稿採択: 平成 8 年 2 月 28 日 別刷請求先 : 高村博光 于852 長崎市坂本町7-1

長崎大学医学部耳鼻咽喉科学教室 